\title{
Temperature (latitude) and nutrient (seabird guano) effects on limno-terrestrial Tardigrada (Testechiniscus spitsbergensis and Pilatobius recamieri) body size
}

\author{
Krzysztof Zawierucha (1),b, Paweł Podkowa (1) ${ }^{\mathrm{c}}$, Martyna Marciniak, Piotr Gąsiorek (1) \\ Katarzyna Zmudczyńska-Skarbek ${ }^{f}$, Karel Janko $\oplus^{\mathrm{b}, \mathrm{g}}$ \& Maria Włodarska-Kowalczuk ${ }^{\mathrm{h}}$
}

\begin{abstract}
aDepartment of Animal Taxonomy and Ecology, Faculty of Biology, Adam Mickiewicz University, Poznań, Poland; bLaboratory of Fish Genetics, Institute of Animal Physiology and Genetics, Academy of Sciences of the Czech Republic, Libechov, Czech Republic; 'Department of Avian Biology and Ecology, Faculty of Biology, Adam Mickiewicz University, Poznań, Poland; 'Department of Animal Morphology, Faculty of Biology, Adam Mickiewicz University, Poznań, Poland; 'Department of Entomology, Faculty of Biology, Jagiellonian University, Kraków, Poland; 'Department of Vertebrate Ecology and Zoology, Faculty of Biology, University of Gdańsk,

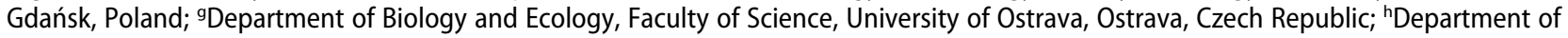
Marine Ecology, Institute of Oceanology, Polish Academy of Sciences, Sopot, Poland
\end{abstract}

\section{ABSTRACT}

Surveys of terrestrial microinvertebrate morphometry, especially spatial patterns of body size at wider geographical scales, including the polar regions, are very scarce. In this study, we focused on Tardigrada, common limno-terrestrial microinvertebrates. Considering Bergmann's rule, originally formulated for endothermic animals, we tested the hypothesis that body length of limno-terrestrial tardigrades augments with increasing latitude and decreasing temperature. Since some of our sampling areas adjoined seabird colonies, we also explored the effects of nutrients from seabird guano deposits. Individual body length of Testechiniscus spitsbergensis was measured in populations obtained from seven localities distributed along a latitudinal gradient extending from $45^{\circ} \mathrm{N}$ (northern Italy) to $79^{\circ} \mathrm{N}$ (northern Svalbard), and for Pilatobius recamieri from three localities in Svalbard $\left(77^{\circ} \mathrm{N}-80^{\circ} \mathrm{N}\right)$. Considering both latitude and proximity to a seabird colony there were significant effects of locality on the body length of $T$. spitsbergensis; however, no clear pattern of increasing individual body size with increasing latitude could be detected. Immense differences in body size may be a signal for cryptic species diversity within this genus. No effect of latitude, or proximity to a seabird colony, on the body length of Arctic populations of $P$. recamieri was documented. Evidently, there is no tendency towards body size increase along the latitudinal gradient in either $T$. spitsbergensis or P. recamieri. Our study, and recent literature, indicates that larger body size in polar regions reported for several groups of micro-fauna may be a taxon-dependent response, and cannot be taken as a universally applicable rule for limnoterrestrial animals.

\section{KEYWORDS}

Arctic; Bergmann's rule; body length; ectotherms; latitudinal patterns; temperature gradient

\section{ABBREVIATIONS}

ANOVA: analysis of variance; DIC: differential interference contrast; Nl: Graian Alps, Italy; PCM: phase contrast microscopy; Sco:

Aberdeenshire, Scotland, UK SvB: Bjørnøya, Svalbard, Norway; SvF: Fuglesangen, Svalbard, Norway; SvH: Hornsund, Svalbard, Norway: SvN: Nordaustlandet, Svalbard, Norway; SvP: Phippsøya, Svalbard, Norway; Tat: Tatra Mountains, Poland; Tro: Tromsø, Norway

\section{Introduction}

Body size is known to be related to longevity, fecundity, the ability to migrate, predator-prey interactions and host-parasite interactions, together with environmental factors such as latitude and altitude (e.g., Atkinson 1994; Johnson et al. 2005; Gardner et al. 2011; Bowden et al. 2015; Laska et al. 2017). The relationship between an organism's body size, temperature and latitude has been frequently discussed in recent literature (e.g., Blackburn et al. 1999; Hildrew et al. 2007; Gardner et al. 2011; Moran \& Woods 2012; O'Gorman et al. 2012; Berke et al. 2013; Horne et al. 2015). One of the major factors affecting body size is temperature (Atkinson 1994; Blackburn et al. 1999; Ashton 2002; Gilloly et al. 2001) - and the systematic effect of increasing latitude (decreasing temperature) on body size of endotherms is one of the commonly encountered biological observations (Bergmann 1847; James 1970). One of the classical ecogeographical explanations for interspecific latitudinal and temperature variation in body size is Bergmann's rule (Bergmann 1847), which states that larger animals have lower surface area to volume ratios, so they lose less heat per unit of mass and as a result would be expected to grow larger in colder regions. However, Bergmann's rule was originally formulated for endothermic animals, and although it has repeatedly been proposed to be applicable more widely (Ashton 2002; Ashton \& Feldman 2003), a number of contradictory patterns are frequently observed in ectotherms (Atkinson 1994;

CONTACT Krzysztof Zawierucha k.p.zawierucha@gmail.com E Department of Animal Taxonomy and Ecology, Faculty of Biology, Adam Mickiewicz University, Poznań, Umultowska 89, PL-61-614 Poznań, Poland

(1) Supplemental data for this article can be accessed here. 
Angilletta \& Dunham 2003; Ashton \& Feldman 2003; Berke et al. 2013). There is also the temperature-size rule that predicts that oxygen demands and different thermal sensitivities in growth and development rate may lead to smaller size at a given age in warmer temperatures (Atkinson 1994). Another remarkable phenomenon, polar gigantism, or more specifically the presence of large representatives of many marine invertebrate groups in polar waters, especially in the Antarctic, has attracted considerable research attention and a quest for a general explanation (Moran \& Woods 2012). Gigantism remains a phenomenon operating at the inter - rather than the intraspecific level, that has led to several theories explaining the physical, ecological and evolutionary constraints on aquatic invertebrate body size (Chapelle \& Peck 1999; Moran \& Woods 2012). Nonetheless, explanations for this biogeographical effect, observed mostly in marine habitats, remain debatable (Moran \& Woods 2012). Body size in some aquatic animals is reduced with both increasing temperature and decreasing latitude, and it is thought that oxygen limitation may be the factor controlling size shifts (Horne et al. 2015). However, contradictory evidence for similar patterns in terrestrial fauna (mostly insects) exist (e.g., Makarieva et al. 2005; Horne et al. 2015), and only limited information on latitudinal patterns in noninsect limno-terrestrial (i.e., species requiring a film of water to maintain life functions in terrestrial environments that often desiccate abruptly) invertebrate groups is available. In terrestrial species, shifts in body size patterns are thought to be related to life histories as well as seasonal temperature changes (Horne et al. 2015, 2017).

Changes in climate have the potential to affect physiology, distribution patterns and phenology of plants and animals (IPCC 2007; Thackeray et al. 2010; Yvon-Durocher et al. 2010; Gardner et al. 2011; Hodkinson 2013), and increasing temperatures may also induce shifts in body size of particular species as well as total biomass at the community level (YvonDurocher et al. 2010; Gardner et al. 2011; Bowden et al. 2015). An understanding of the temperature effects on organism size is especially important in the rapidly changing polar ecosystems in which invertebrates are restricted to only a few groups. These groups play important roles as prey, grazers or predators (e.g., Hodkinson 2013), and body size change in one ecological group or key species may affect the functioning of the entire ecosystem (Gardner et al. 2011). An example of such a size-related functional change is the scenario involving the shift in dominance from a large-bodied Arctic copepod species (Calanus glacialis) to its warm-water, smaller and co-generic species (C. finmarchicus), and the effects of this shift on the survival of the little auk colonies in the Arctic (Stempniewicz et al. 2007).
Until now, little attention has been given to the comparative morphometry of microscopic limno-terrestrial invertebrates living at different latitudes, especially in polar regions. While a number of recent papers have been devoted to body size in Arctic marine or freshwater invertebrates (e.g., Węsławski et al. 2006; Trudnowska et al. 2014; Grzelak et al. 2016; Kolicka et al. 2016; Hirst et al. 2017), the issue remains neglected in polar limno-terrestrial microinvertebrates, with only a handful of studies performed in the Antarctic or Arctic (e.g., Jennings 1976; Zawierucha et al. 2015; Seniczak et al. 2017).

The present study focuses on spatial patterns in size (as indicated by body length) in one of the dominant groups of limno-terrestrial microinvertebrates, namely tardigrades. This group is distributed in all zoogeographical zones, comprising over 1200 taxa (Degma \& Guidetti 2007; Degma et al. 20092017) that inhabit terrestrial, freshwater, brackish and marine environments (Nelson et al. 2015). In limnoterrestrial ecosystems they play important roles in food webs, not only as herbivores, grazers and predators, but also as a food source for other microinvertebrates (Hohberg \& Traunspurger 2005; Nelson et al. 2015; Zawierucha, Ostrowska et al. 2016). Locally they can reach very high densities, up to hundreds of individuals per gram of dry plant or soil sample (e.g., Zawierucha, Zmudczyńska-Skarbek et al. 2016). Nonetheless, detailed experimental (field or laboratory) data are scarce for tardigrade morphometry (e.g., Ramazzotti \& Maucci 1983; Schuster \& Greven 2013; Kosztyła et al. 2016). Recent studies conducted under laboratory conditions have shown that tardigrade morphometric traits may be influenced by the environment (Kosztyła et al. 2016), genetics (Stec et al. 2016) and individual development/ontogeny (Morek, Gąsiorek et al. 2016). Variation in observations due to preparation techniques has also been reported (Morek, Stec et al. 2016). Body size and morphometrics have been used throughout the history of tardigrade research (Pilato 1981; Bartels et al. 2011; Fontoura \& Morais 2011; Kosztyła et al. 2016), yet there is a lack of studies on the impact of latitude on body size. Despite extensive and fully controlled laboratory experiments on the influence of temperature on the phenotypic plasticity and size ranges of tardigrades (Kosztyła et al. 2016; Stec et al. 2016) there remains a paucity of knowledge on tardigrade size variability in the natural environment. Researchers carrying out laboratory studies underlined the possibility that field sampling may reveal additional effects of environmental drivers on tardigrade body size (Kosztyła et al. 2016).

In the study reported here, we explored the latitudinal patterns of body size in two tardigrade species Testechiniscus spitsbergensis (Scourfield, 1897) and Pilatobius recamieri (Richters, 1911). We analysed 
whether body size (indicated by body length) of tardigrades increases towards higher latitudes. Using the time to space analogue approach, we aimed to learn if an increasing global temperature might influence the body size of tardigrades in the Arctic. Moreover, since tardigrade body size could be affected by enhanced food resources found in the nutrientenriched tundra near seabird colonies (Zawierucha et al. 2015), and as some of our study areas adjoined such colonies, we tested the effects of this factor as well.

\section{Material and methods}

\section{Sample collection and processing}

Twenty-two moss, mixed moss/lichen, moss/soil and moss/Salix sp. samples were collected, along the latitudinal gradient from $45^{\circ} \mathrm{N}$ to $80^{\circ} \mathrm{N}$, from nine localities: NI, Tat, Sco, Tro, SvB, SvH, SvF, SvN and SvP (Fig. 1, Supplementary Table S1). Sampling locations included grassland with snow cover during winter from the Alpine region, which lies at the intersection between the Atlantic Ocean, the Mediterranean Sea and the European mainland, characterized by continental air from mainland Europe and a maritime influence (NI), mountains with a humid climate and snow cover during winter (Tat), lowland temperate humid insular climate (Sco), Subarctic highland areas (Tro), tundra, midway between the Norwegian mainland and High-Arctic islands (SvB) to High-Arctic tundra localities (SvH, SvF, SvN, SvP). The distance between the southernmost and the northernmost sampling points in the first gradient is ca. $3853 \mathrm{~km}$. For the NI and the Tat sites, we located climatic data for the nearest location to the sampling sites. However, the values were limited to maximum and minimum average temperatures, with no general monthly averages. Therefore, we used temperatures for those months where both minimum and maximum temperatures remained above $0^{\circ} \mathrm{C}$, i.e., when the soil is not frozen and snow cover is reduced so that the animals may be active. For the other localities the average temperatures were obtained for months with temperatures during day and night above $0^{\circ} \mathrm{C}$. In general average temperatures in periods above $0^{\circ} \mathrm{C}$ ranged from a maximum of ca. $16^{\circ} \mathrm{C}$ and minimum of ca. $7^{\circ} \mathrm{C}$ in the south to an average of $2.5^{\circ} \mathrm{C}$ in northern localities. Sampling locations in the second gradational transect included High-Arctic tundra localities (SvH, SvF, SvP). The distance between the southernmost and the northernmost sampling points in this second transect is ca. $420 \mathrm{~km}$. Average temperatures ranged from $3.5^{\circ} \mathrm{C}$ in the southern locality to $2.2-2.5^{\circ} \mathrm{C}$ in the northern localities. Samples were collected during a season without snow and frost (Supplementary Table S1). All samples were placed

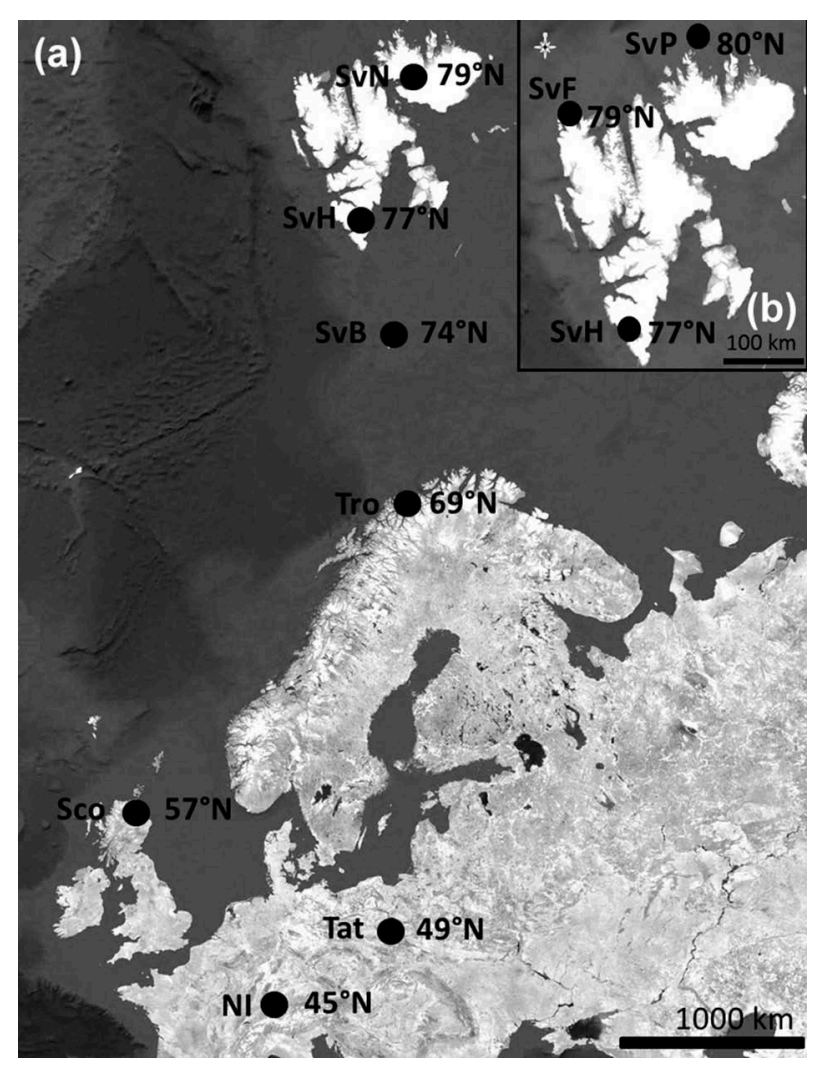

Figure 1. Map with sampling locations for (a) Testechiniscus spitsbergensis and (b) Pilatobius recamieri.

in paper envelopes and left to dry slowly. Analysed samples were of approximate equal size - not more than 2-3 g of the dry material.

Seven samples were collected from Arctic areas that were influenced by seabirds. These areas are characterized by nutrients originating from guano, eggshells and carcasses, which significantly influence soil physicochemical properties that, in turn, result in higher biomass and plant diversity (Eurola \& Hakala 1977; Zwolicki et al. 2013; Zwolicki et al. 2016). Because of their considerable plant biomass, and high plant and animal diversity, these areas were proposed for sampling as they may influence the body size of tardigrades (Zawierucha et al. 2015). For the analysis of nutrient effects on tardigrade body size, samples from areas influenced by seabirds (samples from areas surrounded by bird colonies) and samples not influenced by ornithogenic guano were included. The characteristics of the sampling sites (geographical position, sample type, presence/ absence of seabird colonies, sampling date, elevation above sea level, average temperature, tardigrade species and number of individuals measured) are provided in Supplementary Table S1.

In the laboratory, specimens were isolated by placing a piece of the sample in a beaker filled with water. After a few hours, the material was shaken within the beaker. The supernatant containing tardigrades was then stirred and poured into a $250 \mathrm{ml}$ cylinder. When all particles had settled onto the cylinder 
bottom (after at least $25 \mathrm{~min}$ ), the top layer of water was discarded and the remaining ca. $40-50 \mathrm{ml}$ was stirred and poured onto Petri dishes and scanned under a stereomicroscope in search of tardigrades.

\section{General characteristics of model animals}

Testechiniscus spitsbergensis (Fig. 2a) belongs to the Echiniscidae, possessing an external morphology typical for this family: an exoskeleton strengthened by symmetrically arranged dorsal cuticular plates. It has additional ventral plates and large black eyes, traits that are specific to the genus (Kristensen 1987; Gąsiorek et al. 2018). The species in the genus typically have an Arctic-highmountain distribution, inhabiting Greenland, Iceland, Svalbard and colder localities in continental Europe and Africa (Ramazzotti \& Maucci 1983; Gąsiorek et al. 2018). Because of failure in DNA sequencing and lack of molecular data in the genus Testechniscus, specimens outside of terra typica should be considered as Testechiniscus cf. spitsbergensis until the basic barcodes are available for the group.

Pilatobius recamieri (Fig. 2b) exhibits a combination of traits common within the family Hypsibiidae: asymmetrical claws, with external claws being much longer than internal ones, and the bucco-pharyngeal apparatus subdivided into a rigid anterior portion and a longer flexible posterior portion. Pilatobius recamieri has two macroplacoids and septulum. This species is an indigenous element of the High-Arctic fauna and is rarely reported from the continental Europe (Gąsiorek, Zawierucha et al. 2017).

Both species are thought to feed on algae, bacteria and detritus (Schill et al. 2011; Guil \& SanchezMoreno 2013).

\section{Selection of individuals for morphometry}

We excluded from our analysis those animals not suitably orientated for morphometry (shrunken or bent). The first instars or larvae of $T$. spitsbergensis are easily distinguishable from juvenile and adult specimens by possession of only two claws, i.e., they lack the external claws (Bertolani et al. 1984), whereas first instar of $P$. recamieri can be recognized by their small size (ca. 150-160 $\mu \mathrm{m}$ in length; see Kosztyła et al. 2016 for morphometry of first instars in Eutardigrada). We were therefore able to exclude them from the data set. To avoid confusion related to the presence or dominance of early or old instars in the samples, we developed two models, the main analysis utilized adults only, and the second incorporated all individuals, including the second stage with developed external claws, but lacking a gonopore, i.e., juveniles (Bertolani et al. 1984; Gąsiorek, Stec et al. 2017). In T. spitsbergensis juveniles can readily be distinguished from sexually mature adults by the absence of a gonopore. Observations made under

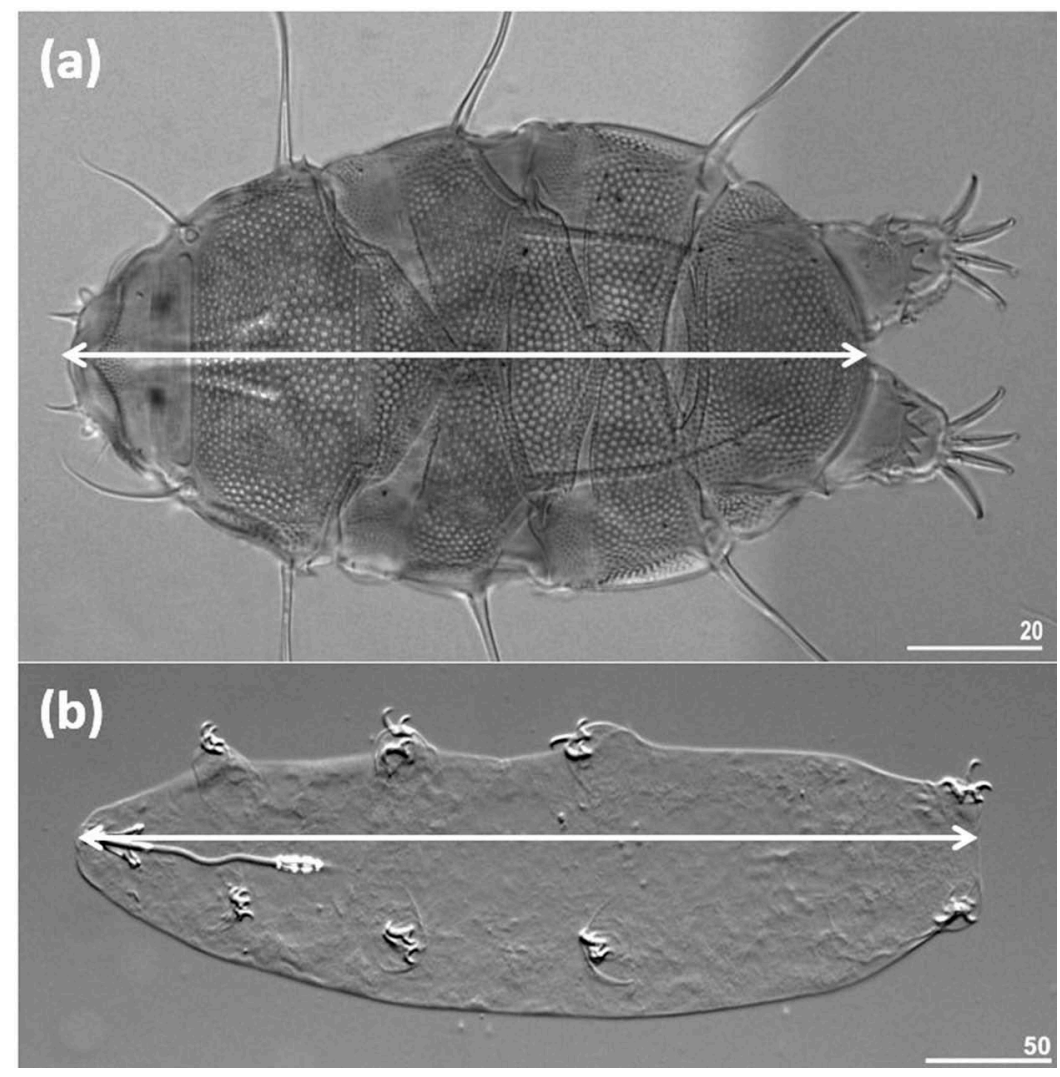

Figure 2. Tardigrada: (a) Testechiniscus spitsbergensis (under PCM); (b) Pilatobius recamieri (under DIC). The main white axis indicates body length used in measurements. The scale bars are in $\mu \mathrm{m}$. 
PCM of both sexually immature and adult specimens revealed no significant morphometric differences between these two stages (Zawierucha, Gąsiorek pers. obs.). Therefore, to exclude both larvae (in $T$. spitsbergensis) and first instar (in P. recamieri) from consideration within the main analysis we included only those specimens with length equal to or greater than $200 \mu \mathrm{m}$. By excluding both larvae and very small specimens, we were able to minimize the effect of instars within the main analysis. In the second analysis we included all individuals (with the exception of first instars).

\section{Measurements and data analyses}

Tardigrade individuals were mounted on microscope slides in a small drop of Hoyer's medium and examined under an Olympus BX53 PCM associated with an ARTCAM 500 digital camera. The sample size (the number of individuals which allowed confident interpretation of dimensions) for morphometric analysis was chosen following recommendations provided by Stec et al. (2016). Based on the statistical treatment of large data sets of tardigrade morphometric measurements, they recommend 16-18 specimens (for members of the Hypsibiidae, e.g., $P$. recamieri) as the minimum number of individuals needed to obtain means for traits that are not significantly different from the population values. There is a lack of information relating to optimal sample size, for morphometry, for heterotardigrades (e.g., T. spitsbergensis). However, as 19 measurements are thought to provide an overall average for Eutardigrada (e.g., P. recamieri), we measured a minimum of 21 individuals of $T$. spitsbergensis. All measurements $(\mu \mathrm{m})$ were performed under PCM using the QuickPHOTO CAMERA 3.0. software.

The best method for estimation of eutardigrade body size is measurement of buccal tube length (e.g., Bartels et al. 2011). However, in our specimens the buccal tubes were not arranged in one plane, so it was difficult to obtain at the correct angle for morphometry. We therefore decided to directly measure the body length of suitably orientated specimens from the anterior to the posterior end of the body, excluding the hind legs. For species identification, the keys of Ramazzotti \& Maucci (1983) and Dastych (1988), together with a recent re-descriptions of $P$. recamieri and T. spitsbergensis by Gąsiorek, Zawierucha et al. and (2017) and Gąsiorek et al. (2018) were used.

In total 257 individuals of T. spitsbergensis and 69 individuals of $P$. recamieri were analysed. Body lengths of $T$. spitsbergensis were recorded from seven locations (see first gradient; Fig. 1a). NI (54 individuals from one moss sample), Tat (42 individuals from two moss samples), Sco (28 individuals from one moss sample), Tro (26 individuals from one moss sample), SvB (29 individuals from three moss/ soil and one moss/Salix sp. samples), SvH (57 individuals from four moss samples), SvN (21 individuals from one moss/soil sample). For $P$. recamieri measurements were performed on specimens collected from three Svalbard locations (second gradient, Fig. 1b). SvH (18 individuals from five moss samples), SvF (21 individuals from one moss sample) and SvP (30 individuals from one moss and one moss/ lichen sample).

Investigations into the response of body size to external stimuli depend very much on whether the collected data set is statistically suited for the detection of any such response. For example, even if there would be a significant, yet small, change of body size with the latitude, a small data set and/or high variability characterizing individuals within a single population may outweigh the trend and cause a false negative observation. In order to evaluate whether the collected data have sufficient power to detect biologically relevant changes in body size, we performed the following thought experiment. Kosztyła et al. (2016) exposed six tardigrade species to changes in temperature and food regimes and observed, on average, a $12 \%$ change in body size between the most extreme treatments. This experiment therefore sets a range where one may expect a change in body size to occur in response to external stimuli. To evaluate the power of our data we conservatively assessed whether an average $6 \%$ change in body size between the extremes in the sampled gradient could be detected using our data set, taking into consideration the realsize variance. Specifically, we compared the original data of 42 individuals from the southernmost site (NI) with the simulated data set of 42 individuals that increased their size by an average factor of $6 \%$. To do so, we first generated 42 random numbers from the normal distribution with a mean of 0.06 (corresponding to expected change in body size by $6 \%)$ and relatively large SD (0.07). Subsequently, we used these numbers to multiply the original data set of 42 individual lengths and therefore obtained a simulated data set in which tardigrades from NI were artificially increased on average by $6 \%$ while keeping the dispersion of the original data (note that the SD used for the simulated data ensured that the maximum/minimum values of the simulated data set would not differ by more than $12 \%$ from the maximum/minimum in the original data). Finally, we used Student's t-test to evaluate whether the modified data sets significantly differed from the original data. The simulations for the northern site $(\mathrm{SvH})$ were done analogously except that the original data were decreased in size.

For each species, the variation in body length was analysed using a type III sum of squares linear 
model with "seabird" (the presence or absence of a seabird colony within a study location) and "locality" as the grouping factors. We also used the "altitude" as a numerical covariate, and also conducted a one-way ANOVA to test the differences between all localities with the Hochberg's GT2 post-hoc test for unequal groups. We tested the data distribution by using the Shapiro-Wilk test (for histograms see Supplementary Fig. S1). All tests were two-tailed and the alpha level for significant differences was set to 0.05 . All statistical analyses were conducted in SPSS Statistics (version 23, IBM). In the main analysis (an approach further called "adults only") we removed seven juveniles - as each specimen was below $200 \mu \mathrm{m}$ - from the following T. spitsbergensis samples: Tat - 3, Sco - 1, SvH - 1, SvN - 2. For T. spitsbergensis we conducted an additional analysis including juveniles but without first instars (an approach named "all individuals"; see Supplementary Tables S2 and S3 for details).

\section{Results}

The mean body length of $T$. spitsbergensis in the main analysis from all seven populations ranged from $278.6 \mu \mathrm{m}$ (Tro) to $330 \mu \mathrm{m}$ (Sco). The smallest $(207 \mu \mathrm{m})$ and the largest $(410 \mu \mathrm{m})$ individuals of $T$. spitsbergensis within the main analysis were found in $\mathrm{SvH}$ and NI respectively. The mean body length of $P$. recamieri from all three populations ranged in the main analysis from $300.1 \mu \mathrm{m}(\mathrm{SvH})$ to $323.7 \mu \mathrm{m}(\mathrm{SvP})$. The smallest $(205 \mu \mathrm{m})$ and the largest $(407.4 \mu \mathrm{m})$ individuals of $P$. recamieri were found in $\mathrm{SvF}$ and $\mathrm{SvH}$, respectively. We did not find any differences between the average body size in those groups incorporating all individuals (i.e., including animals below $200 \mu \mathrm{m}$, considered as early juveniles) and those composed of adults only (i.e., excluding animals below $200 \mu \mathrm{m}$ ). Basic statistics for all individuals (mean, CI, SE, min., max. body size) of T. spitsbergensis and $P$. recamieri are given in Supplementary Table S2.

We performed a simulation study to test if our data had sufficient power to detect biologically relevant changes in tardigrade size along the studied transect. Specifically, we confirmed that even a relatively minor body size change ( $6 \%$ on average with relatively large variance among individuals) between the two extremes of a transect results in highly significant differences. This confirmed that if such potential body size change had occurred along the transect, it would have been detected within our data set.

For T. spitsbergensis, the results of the linear model revealed a statistically significant effect of locality $\left(F_{(6,240)}=7.974, p<0.001\right.$; Supplementary Table S3, Fig. 3), with respect to the presence of seabird colony

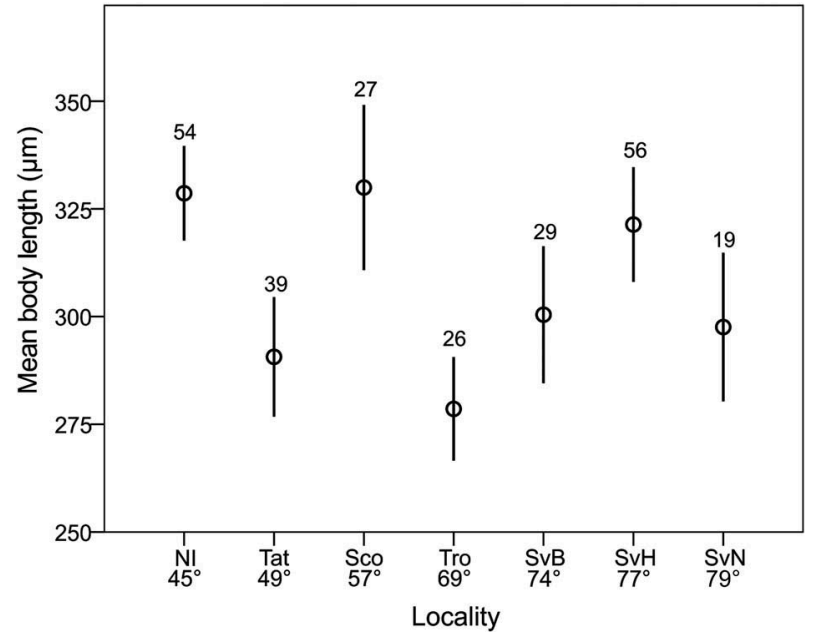

Figure 3. Mean values ( $\pm 0.95 \mathrm{Cl}$ ) of Testechiniscus spitsbergensis body length in seven analysed localities. Numbers above the bars indicate sample size.

$\left(F_{(1,240)}=5.130, p=0.024\right)$, on the body length of individuals. Both the altitude $\left(F_{(1,240)}=2.655\right.$, $p=0.105)$ and the interaction of latitude and seabird presence were not statistically significant. Nevertheless, the strongest effect on body length was related to latitude. We conducted the post-hoc test which revealed differences between the following localities: NI> Tat, Tro; $\mathrm{Sc}>$ Tat, Tro; $\mathrm{SvH}>$ Tat, Tro (Table 1). However, these significant differences are not related to latitudinal variation.

By using the same model in $P$. recamieri, as utilized in T. spitsbergensis, we did not find any statistically significant effects as a result of, seabird presence $\left(F_{(1,64)}=1.312, p=0.256\right)$, locality $\left(F_{(2,64)}=2.695\right.$, $p=0.075$, Fig. 4), or altitude $\left(F_{(1,64)}=1.311\right.$, $p=0.257)$ on the body length of individuals. However, the effect of seabird colony was statistically significant in the model that did not included altitude as a covariate $\left(F_{(1,65)}=7.286, p=0.009\right.$; see more details in Supplementary Table S3). Although Pilatobius recamieri exhibited increasing body size with increasing latitude, the pattern was not significant.

Data detailing the distribution of tardigrade body size for each location are provided in Supplementary Fig. S1.

Table 1. Significance $(p)$ values of Hochberg's GT2 post-hoc test for differences in Testechiniscus spitsbergensis body length between different localities. In Pilatobius recamieri all differences between localities were statistically not significant.

\begin{tabular}{|c|c|c|c|c|c|c|c|}
\hline & & $\mathrm{NI}$ & Tat & Sco & Tro & SvB & $\mathrm{SvH}$ \\
\hline Locality & Latitude $\left({ }^{\circ} \mathrm{N}\right)$ & 45 & 49 & 57 & 69 & 74 & 77 \\
\hline Tat & 49 & 0.001 & & & & & \\
\hline Sco & 57 & $\mathrm{n} / \mathrm{s}$ & 0.006 & & & & \\
\hline Tro & 69 & $<0.001$ & $\mathrm{n} / \mathrm{s}$ & $<0.001$ & & & \\
\hline SvB & 74 & $\mathrm{n} / \mathrm{s}$ & $\mathrm{n} / \mathrm{s}$ & $n / s$ & $\mathrm{n} / \mathrm{s}$ & & \\
\hline $\mathrm{SvH}$ & 77 & $\mathrm{n} / \mathrm{s}$ & 0.014 & $\mathrm{n} / \mathrm{s}$ & 0.001 & $\mathrm{n} / \mathrm{s}$ & \\
\hline SvN & 80 & $n / s$ & $\mathrm{n} / \mathrm{s}$ & $\mathrm{n} / \mathrm{s}$ & $\mathrm{n} / \mathrm{s}$ & $\mathrm{n} / \mathrm{s}$ & $\mathrm{n} / \mathrm{s}$ \\
\hline
\end{tabular}




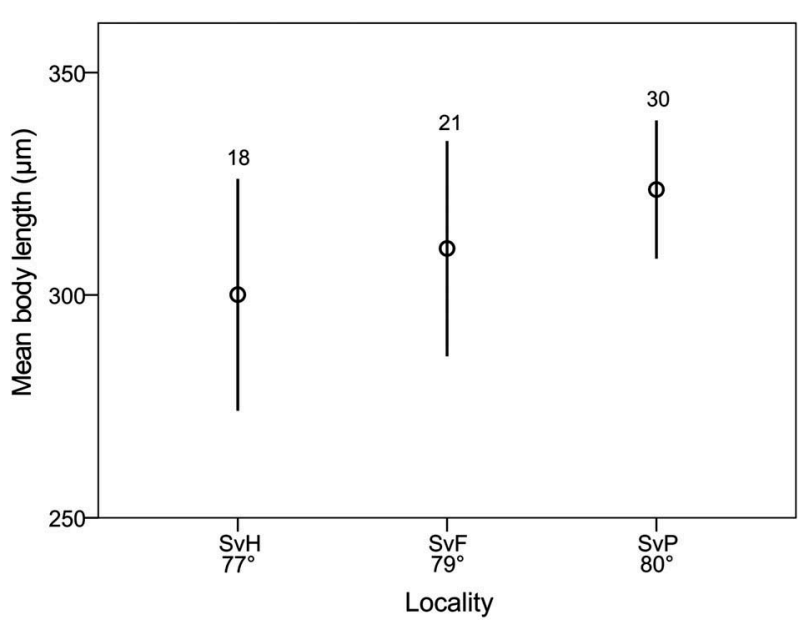

Figure 4. Mean ( $\pm 0.95 \mathrm{Cl}$ ) body length of Pilatobius recamieri in three localities on Svalbard. Sample size indicated above the bars.

\section{Discussion}

We did not find any clear linear response in body size with increasing latitude/decreasing temperature in either of the studied species. Nevertheless, the strongest effect on body length was related to the locality. Kosztyła et al. (2016) studied the phenotypic plasticity of taxonomically meaningful traits under laboratory conditions for eutardigrades (including the family Hypsibiidae Pilato, 1969, to which $P$. recamieri belongs). The authors demonstrated that tardigrades grow largest at low temperatures, whereas the smallest animals were observed under the highest temperatures. However, the significant differences were only observed between the $8^{\circ} \mathrm{C}$ and $20^{\circ} \mathrm{C}$ treatments - a temperature difference of $12^{\circ} \mathrm{C}$. On the other hand, in one species (belonging to the genus Milnesium) Kosztyła et al. (2016) found no differences in morphological traits (body size, buccal apparatus, claw length) and they highlighted that a much wider range of intraspecific phenotypic variation, formed by environmental factors, other than temperature, was likely to be found in tardigrades collected directly from the field. The lack of any tardigrade body size response to latitudinal gradient and variability in temperature presented in our study is in accordance with, and confirms, the assumptions put forward by Kosztyła et al. (2016) that other factors may influence variability.

Studies conducted on beetles from two regions (Marion Island, Heard Island) showed that their body size differs in response to a combination of seasonality and altitude (Chown \& Klok 2003). On non-seasonal islands, body size was found to increase with altitude, whereas on islands with distinct seasons the opposite pattern was found (Chown \& Klok 2003). Tardigrade body size may respond to seasonal variability in environmental factors and altitude but such a relationship has not been demonstrated. Four of our localities with T. spitsbergensis (NI, Tat, Sco and Tro) are located in strongly seasonal areas (presence of four seasons during a year). Therefore, the effects of latitude and altitude may effectively counterbalance each other (note that Arctic and Subarctic locations are the lowest, Sco intermediate, and NI and Tat are the highest locations [a.s. 1.]). An alternative explanation for the observed lack of latitudinal response may stem directly from the predilection of the studied species for polar and cold habitats (Ramazzotti \& Maucci 1983; Dastych 1988). These species are known mainly from upland and mountainous regions in continental Europe, while in the far north, they occur even at low elevation (Zawierucha et al. 2016). Generalizations about the effect of latitude on the pattern of distribution of a species may therefore be misleading, as at lower latitudes altitude may be a significant driver of species distribution and size.

Tardigrades are invertebrates having a number of instars during their life history and many generations during a year (Franceschi et al. 1962-1963; Ramazzotti \& Maucci 1983; Schuster \& Greven 2013; Kosztyła et al. 2016). Multi-voltinism and seasonality in terrestrial arthropods have been discussed as factors that may be related to body size changes along temperature and latitudinal gradients (Horne et al. 2015, 2017). Horne et al. (2015), found that multi-voltine terrestrial species grew larger during the warmer seasons, whereas the body size of aquatic arthropods reduced. The effects of voltinism and seasonal thermal changes on limno-terrestrial tardigrade body size remains unclear but are likely to be complex given that the limno-terrestrial habitat occupies a position that is neither fully terrestrial nor aquatic.

Although seasonal variability may result in shifts of body size, such effect has not been widely accepted. Schuster \& Greven (2013) sampled monthly (over a period of 4.5 years) a lawn covered by a moss carpet and reported that two of the three tardigrade species studied were larger during springtime following a period of cryobiosis in winter. The authors hypothesized that reduced exposure to sunlight negatively affected the body lengths of these two tardigrade species. Angilletta \& Dunham (2003) and Moran \& Woods (2012) highlighted that multiple factors may influence body size simultaneously, and that animal size most likely evolves in a taxon-dependent way. Altitude and seasonality may have some impact on body size but conflicting evidence, derived from the published literature for both endotherms and ectotherms, indicates that both an increase or a decrease in body size is possible (Hamilton 1961; Haas et al. 1977; Chown \& Klok 2013). Such changes may therefore reflect a taxondepended response. In a long-term eight-year study on the structure and function of aquatic communities in streams in Iceland, it was shown that some species of diatoms, chironomids and other macroinvertebrates decreased in size with increasing temperature, still most showed no change, or even an increase, in individual body size with water increasing temperature (O'Gorman 
et al. 2012), which again confirms that body size may be influenced multidirectionally and is likely taxon-specific.

The phylum Tardigrada is able to inhabit diverse and extreme environments, i.e., on account of its small size, ensuing simplification of the body plan, easy dispersion and cryptobiosis - an ametabolic life state (e.g., Wright et al. 1992; Nielsen 2001; Nelson et al. 2015). This study includes localities in the Arctic where the growing season is short, the soil is frozen for most of the year and tardigrades are likely to enter cryptobiosis to survive the polar winter season. Jönsson \& Rebecchi (2002) suggested that body size may influence tardigrade capability to survive in cryptobiosis, ipso facto Arctic animals should be bigger than their more temperate counterparts. Contrary to Jönsson \& Rebecchi (2002), we found that our Arctic specimens of $T$. spitsbergensis were not the biggest, and that instead the largest were found in locations NI (northern Italy) and Sco (Scotland) where, unlike the Arctic, the soil remains unfrozen for the most of the year. Moreover, Czernekova \& Jönsson (2016) used tardigrade specimens in a recent experiment and desiccated them under controlled relative humidity. After each desiccation cycle water bears were selected for morphometric analysis. No significant differences were found with respect to body length among trials, including desiccated animals and controls, indicating that cryptobiosis does not change body size (Czernekova \& Jönsson 2016).

The effect of seabird guano enrichment was documented only for T. spitsbergensis. In the generally nutrient-poor Arctic terrestrial ecosystem, seabird colonies support some of the richest habitats, and typically have a relatively high plant biomass and animal densities (e.g., Zmudczyńska et al. 2012; Zawierucha, ZmudczyńskaSkarbek et al. 2016; Zwolicki et al. 2016). This happens because of the ornithogenic transport of marine nutrients to land, mainly in the form of guano, and fertilization of the soil with nitrogen, potassium, phosphorus and many other elements (Eurola \& Hakala 1977; Zwolicki et al. 2013; Zwolicki et al. 2016). For the same reason, the individual size of some plant species was found to be considerably greater close to seabird colonies compared with areas more distant from them (Zmudczyńska et al. 2008; Zmudczyńska-Skarbek et al. 2013; Wojciechowska et al. 2015). Previously, we found that tardigrades were also significantly larger in the seabird-fertilized sites compared to areas beyond their impact, and suggested that this may be an effect of greater food availability (Zawierucha et al. 2015). Such findings are in line with our observations for $T$. spitsbergensis but contrast with the results for our second species, $P$. recamieri, where no influence on specimen size, associated with proximity to seabird colonies, was noted. This finding may simply reflect the characteristics of the species used in the study, and the fact that the two species belong to different orders. If so, it implies that their response to seabird colony proximity may be taxon-dependent. Zawierucha et al. (2015) studied an omnivorous tardigrade species Diaforobiotus islandicus (Richters, 1904) which, apart from algae and bacteria, may also feed on other microinvertebrates, which are more abundant in the vicinity of seabird colonies. The genera Testechiniscus and Pilatobius belong to the herbivorous and microbivorous trophic groups, respectively. They both have narrow buccal tubes (with external diameters typically around 2 $\mu \mathrm{m})$ and feed mainly on plant cells, algae, yeast and bacteria (Schill et al. 2011; Guil \& Sanchez-Moreno 2013). However, the exact food preferences of these species remain unknown. The available pool of the food sources available to each species may actually be imperceptibly changed by the seabird colonies, to the benefit of T. spitsbergensis while still being sufficient to support $P$. recamieri but insufficient to affect a change in its body size. Kosztyła et al. (2016) showed in an experimental study that the tardigrade size reaction to changing food levels (standardized quantity of food designed to match the diet of particular species: algae for herbivorous and rotifers for predators) was species-specific: out of the six species used only two exhibited significant effects.

The expected increase in body size with latitudinal gradient could be masked by differences in the proportion of each instar (disparate body size classes) in the samples. For example, a higher proportion of younger instars in the Arctic region samples compared to the more southern sites may effectively mask any actual increase in body size variation along the latitudinal gradient. Such argument, however, may not explain our observation as there were only a small number of juveniles of $T$. spitsbergensis in Hornsund in Svalbard (see Supplementary Table S2). Moreover, the size distributions did not significantly deviate from normality, indicating that our site-specific data sets were not dominated by any specific instar. In natural environments, body size change may be affected by factors other than those discussed above (e.g., Brooks \& Dodson 1965; Briggs et al. 2012; Moran \& Woods 2012). Experimental manipulations, as well as long-term field experiments, show that top predator body size can trigger cascading effects at lower trophic levels, with resultant modification of ecosystem process rates (Jochum et al. 2012; O'Gorman et al. 2012). For example, the presence of predators may trigger selection pressure through selection of larger prey (e.g., Brooks \& Dodson 1965). The lack of the expected pattern of gradually increasing tardigrade body size with latitude may also result from variability during the animals' life histories. It may also illustrate cryptic species diversity within tardigrades (Faurby et al. 2008). However, the problem of life histories is excluded in this study by removal of extremely small individuals, as well as by the fact that the size of instars overlaps (De Smet \& Van Rompu 1994; 
Kosztyła et al. 2016). Cryptic diversity within invertebrates may be revealed chiefly by global sampling combined with molecular comparisons of specimens and studies on their phenotypic plasticity (Jørgensen et al. 2007; Cesari et al. 2016; Kosztyła et al. 2016).

Tardigrada are a group of poorly known metazoans for which data on phenotypic plasticity and ecological relations in natural environments are scarce. In conclusion then, the lack of an expected pattern, i.e., a gradual changes in tardigrade body size with increasing latitude, suggests that gradual temperature changes do not influence $T$. spitsbergensis or P. recamieri body size in the natural environment. It is likely that other factors, such as prey selection by predators (e.g., tardigrades selected by mites) or competition for food, may affect tardigrade body size. Conflicting signals (found within our study and in the published literature we consulted) that indicate both an increase and a decrease in body size in response to temperature or other factors may be explained as a taxon-dependent response.

\section{Acknowledgements}

The remarks and suggestions of two anonymous reviewers greatly improved the paper, and we are gratefully indebted to them. We thank Professor Stephen J. Coulson (University Centre in Svalbard, ArtDatabanken, The Swedish Species Information Centre, Swedish University of Agricultural Sciences) and Brian Blagden (The Scottish Environment Protection Agency) for collecting samples in Nordaustlandet (Svalbard) and Aberdeenshire, respectively. Brian Blgaden also critically read the manuscript and made necessary linguistic corrections, as did Katherine Short (British Antarctic Survey). Special thanks go also to Professor Łukasz Kaczmarek (Adam Mickiewicz University) and Jerzy Smykla (Polish Academy of Sciences) for sharing material collected in 2010 from Hornsund. KZ thanks Daniel Stec (Jagiellonian University) for comments on the Results section and Lidia Szymkowiak for help with part of the measurements. KJ thanks to the Czech Arctic Research Infrastructure Josef Svoboda Station.

\section{Disclosure statement}

No potential conflict of interest was reported by the authors.

\section{Funding}

Studies were conducted as part of the Polish-Norwegian Research Programme, operated by the National Centre for Research and Development under the Norwegian Financial Mechanism 2009-2014 in the framework of project contract no. Pol-Nor/201992/93/2014 (DWARF). The study was supported by the Polish Ministry of Science and Higher Education via the Diamond Grant programme (grant no. DIA 2011035241, to KZ) and by the project EXCELLENCE (grant no. CZ.02.1.01/0.0/0.0/15_003/ 0000460 OP RDE to KJ and KZ). During this study, KZ was a beneficiary of a National Science Centre scholarship to support doctoral research (no. 2015/16/T/NZ8/00017). $\mathrm{KJ}$ is supported by project CzechPolar2 and project ECOPOLARIS no. CZ.02.1.01/0.0/0.0/16_013/0001708.

\section{ORCID}

Krzysztof Zawierucha (D) http://orcid.org/0000-0002-07541411

Paweł Podkowa (D) http://orcid.org/0000-0001-8148-9968

Piotr Gąsiorek (D) http://orcid.org/0000-0002-2814-8117

Karel Janko (D) http://orcid.org/0000-0002-7866-4937

\section{References}

Angilletta M.J. Jr. \& Dunham A.E. 2003. The temperaturesize rule in ectotherms: simple evolutionary explanations may not be general. The American Naturalist 162, 332342.

Ashton K.G. 2002. Patterns of within-species body size variation of birds: strong evidence for Bergmann's rule. Global Ecology and Biogeography 11, 505-523.

Ashton K.G. \& Feldman C.R. 2003. Bergmann's rule in nonavian reptiles: turtles follow it, lizards and snakes reverse it. Evolution 57, 1151-1163.

Atkinson D. 1994. Temperature and organism size-a biological law for ectotherms? Advances in Ecological Research 25, 1-58.

Bartels P.J., Nelson D.R. \& Exline R.P. 2011. Allometry and the removal of body size effects in the morphometric analysis of tardigrades. Journal of Zoological Systematics and Evolutionary Research 49, 17-25.

Bergmann C. 1847. Über die Verhältnisse der Wärmeökonomie der Thiere zu ihrer Grösse. (On the relations of the heat economy of animals to their size.) Göttinger Studien 3, 595-708.

Berke S.K., Jablonski D., Krug A.Z., Roy K. \& Tomasovych A. 2013. Beyond Bergmann's rule: size-latitude relationships in marine Bivalvia world-wide. Global Ecology and Biogeography 22, 173-183.

Bertolani R., Grimaldi De Zio S., D’Addabbo Gallo M. \& Morone De Lucia M.R. 1984. Postembryonic development in heterotardigrades. Monitore Zoologico Italiano 18, 307-320.

Blackburn T.M., Gaston K.J. \& Loder N. 1999. Geographic gradients in body size: a clarification of Bergmann's rule. Diversity and Distributions 5, 165-174.

Bowden J.J., Eskildsen A., Hansen R.R., Olsen K., Kurle C. M. \& Høye T.T. 2015. High-Arctic butterflies become smaller with rising temperatures. Biology Letters 11, article no. 20150574, doi: 10.1098/rsbl.2015.0574.

Briggs A.A., Young H.S., McCauley D.J., Hathaway S.A., Dirzo R. \& Fisher R.N. 2012. Effects of spatial subsidies and habitat structure on the foraging ecology and size of geckos. PLoS One 7, e41364. doi: 10.1371/journal. pone.0041364.

Brooks J.L. \& Dodson S.I. 1965. Predation, body size, and composition of plankton. Science 150, 28-35.

Cesari M., McInnes S., Bertolani R., Rebecchi L. \& Guidetti R. 2016. Genetic diversity and biogeography of the south polar water bear Acutuncus antarcticus (Eutardigrada: Hypsibiidae)-evidence that it is a truly pan-Antarctic species. Invertebrate Systematics 30, 635-649.

Chapelle G. \& Peck L.S. 1999. Polar gigantism dictated by oxygen availability. Nature 399, 114-115.

Chown S.L. \& Klok J.C. 2003. Altitudinal body size clines: latitudinal effects associated with changing seasonality. Ecography 26, 445-455.

Czernekova M. \& Jönsson K.I. 2016. Experimentally induced repeated anhydrobiosis in the Eutardigrade Richtersius 
coronifer. PLoS One 11, e0164062, doi: 10.1371/journal. pone.0164062.

Dastych H. 1988. The Tardigrada of Poland. Monografie Fauny Polski 16. Warsaw: Państwowe Wydawnictwo Naukowe.

De Smet W.H. \& Van Rompu E.A. 1994. Rotifera and Tardigrada from some cryoconite holes on a Spitsbergen (Svalbard) glacier. Belgian Journal of Zoology 124, 27-37.

Degma P., Bertolani R. \& Guidetti R. 2009-2017. Actual checklist of Tardigrada species. http://www.tardigrada.modena. unimo.it/miscellanea/Actual\%2 0 checklist $\% 20$ of $\%$ 20Tardigrada.pdf on 7 August 2017.

Degma P. \& Guidetti R. 2007. Notes to the current checklist of Tardigrada. Zootaxa 1579, 41-53.

Eurola S. \& Hakala A.V.K. 1977. The bird cliff vegetation of Svalbard. Aquilo: Seria Botanica 15, 1-18.

Faurby S., Jönsson K.I., Rebecchi L. \& Funch P. 2008. Variation in anhydrobiotic survival of two eutardigrade morphospecies: a story of cryptic species and their dispersal. Journal of Zoology 275, 139-145.

Fontoura P. \& Morais P. 2011. Assessment of traditional and geometric morphometrics for discriminating cryptic species of the Pseudechiniscus suillus complex (Tardigrada, Echiniscidae). Journal of Zoological Systematics and Evolutionary Research 49, 26-33.

Franceschi T., Loi M.L. \& Pierantoni R. 1962-1963. Risultati di una prima indagine ecologica condotta su popolazioni di Tardigradi. (Results of a first ecological survey conducted on tardigrade populations.) Bollettino dei Musei e degli Istituti Biologici dell'Università di Genova 32, 69-93.

Gardner J.L., Peters A., Kearney M.R., Joseph L. \& Heinsohn R. 2011. Declining body size: a third universal response to warming? Trends in Ecology \& Evolution 26, 285-291.

Gąsiorek P., Stec D., Morek W. \& Michalczyk Ł. 2017. An integrative redescription of Echiniscus testudo (Doyère, 1840), the nominal taxon for the class Heterotardigrada (Ecdysozoa: Panarthropoda: Tardigrada). Zoologischer Anzeiger 270, 107-122.

Gąsiorek P., Zawierucha K., Stec D. \& Michalczyk Ł. 2017. Integrative redescription of a common Arctic water bear Pilatobius recamieri (Richters, 1911). Polar Biology 40, 2239-2252.

Gąsiorek P., Stec D., Zawierucha K., Kristensen R.M. \& Michalczyk Ł. 2018. Revision of Testechiniscus Kristensen, 1987 (Heterotardigrada: Echiniscidae) refutes the polartemperate distribution of the genus. Zootaxa.

Gillooly J.F., Brown J.H., West G.B., Savage V.M. \& Charnov E.L. 2001. Effects of size and temperature on metabolic rate. Science 293, 2248-2251.

Grzelak K., Goluchowska M., Gregorczyk K., Winogradowa A. \& Węslawski J.M. 2016. Nematode biomass and morphometric attributes as biological indicators of local environmental conditions in Arctic fjords. Ecological Indicators 69, 368-380.

Guil N. \& Sanchez-Moreno S. 2013. Fine-scale patterns in micrometazoans: tardigrade diversity, community composition and trophic dynamics in leaf litter. Systematics and Biodiversity 11, 181-193.

Haas J.D., Baker P.T. \& Hunt E. Jr. 1977. The effects of high altitude on body size and composition of the new born infant in southern Peru. Human Biology 49, 611-628.

Hamilton T.H. 1961. The adaptive significances of intraspecific trends of variation in wing length and body size among bird species. Evolution 15, 180-195.

Hildrew A.G., David G., Raffaelli D.G. \& Edmonts-Brown R. (eds.) 2007. Body size: the structure and function of aquatic ecosystems. Cambridge: Cambridge University Press.
Hirst A.G., Lilley M.K.S., Glazier D.S. \& Atkinson D. 2017. Ontogenetic body-mass scaling of nitrogen excretion relates to body surface area in diverse pelagic invertebrates. Limnology and Oceanography 62, 311-319.

Hodkinson I.D. 2013. Terrestrial and freshwater invertebrates. In H. Meltofte (ed.): Arctic biodiversity assessment. Status and trends in Arctic biodiversity. Pp. 194223. Akureyri: Conservation of Arctic Flora and Fauna.

Hohberg K. \& Traunspurger W. 2005. Predator-prey interaction in soil food web: functional response, size-depentent foraging efficiency, and the influence of soil texture. Biology and Fertility of Soils 41, 419-427.

Horne C.R., Hirst A.G. \& Atkinson D. 2015. Temperaturesize responses match latitudinal-size clines in arthropods, revealing critical differences between aquatic and terrestrial species. Ecology Letters 18, 327-335.

Horne C.R., Hirst A.G. \& Atkinson D. 2017. Seasonal body size reductions with warming co-vary with major body size gradients in arthropod species. Proceedings of the Royal Society B 284, article no. 20170238, doi: 10.1098/ rspb.2017.0238.

IPCC 2007. Summary for policymakers. In M.L. Parry, et al. (eds.): Climate change 2007. Impacts, adaptation and vulnerability. Contribution of Working Group II to the fourth assessment report of the Intergovernmental Panel on Climate Change. Pp. 79-133. Cambridge: Cambridge University Press.

James F.C. 1970. Geographic size variation in birds and its relationship to climate. Ecology 51, 365-390.

Jennings P.G. 1976. Tardigrada from the Antarctic Peninsula and Scotia Ridge region. British Antarctic Survey Bulletin 44, 77-95.

Jochum M., Schneider F.D., Crowe T.P., Brose U. \& O'Gorman E.J. 2012. Climate induced changes in bottom-up and topdown processes independently alter marine ecosystems. Philosophical Transactions of the Royal Society of London, Series B, Biological Sciences 367, 2962-2970.

Johnson K.P., Bush S.E. \& Clayton D.H. 2005. Correlated evolution of host and parasite body size: tests of Harrison's rule using birds and lice. Evolution 59, 1744-1753.

Jönsson K.I. \& Rebecchi L. 2002. Experimentally induces anhydrobiosis in the tardigrade Richtersius coronifer: phenotypic factors affecting survival. Journal of Experimental Zoology 293, 578-584.

Jørgensen A., Mobjerg N. \& Kristensen R.M. 2007. A molecular study of the tardigrade Echiniscus testudo (Echiniscidae) reveals low DNA sequence diversity over a large geographical area. Journal of Limnology 66, 77-83.

Kolicka M., Dabert M., Dabert J., Kånneby T. \& Kisielewski J. 2016. Bifidochaetus, a new Arctic genus of freshwater Chaetonotida (Gastrotricha) from Spitsbergen revealed by an integrative taxonomic approach. Invertebrate Systematics 30, 398-419.

Kosztyła P., Stec D., Morek W., Gąsiorek P., Zawierucha K., Michno K., Ufir K., Małek D., Hlebowicz K., Laska A., Dudziak M., Frohme M., Prokop Z.M., Kaczmarek Ł. \& Michalczyk Ł. 2016. Experimental taxonomy confirms the environmental stability of morphometric traits in a taxonomically challenging group of microinvertebrates. Zoological Journal of the Linnean Society 178, 765-775.

Kristensen R.M. 1987. Generic revision of the Echiniscidae (Heterotardigrada), with a discussion of the origin of the family. In R. Bertolani (ed.): Biology of Tardigrada. Proceedings of the 4th International Symposium on the Tardigrada, Modena, September 3-5, 1985. Pp. 261-335. Modena: Mucchi. 
Laska A., Rector B., Kuczyński B. \& Skoracka A. 2017. Is body size important? Seasonal changes in morphology in two grass-feeding Abacarus mites. Experimental and Applied Acarology 72, 317-328.

Makarieva A.M., Gorshkov V.G. \& Li B.L. 2005. Temperature-associated upper limits to body size in terrestrial poikilotherms. Oikos 111, 425-436.

Moran A.L. \& Woods H.A. 2012. Why might they be giants? Towards an understanding of polar gigantism. Journal of Experimental Biology 215, 1995-2002.

Morek W., Gąsiorek P., Stec D., Blagden B. \& Michalczyk Ł. 2016. Experimental taxonomy exposes ontogenetic variability and elucidates the taxonomic value of claw configuration in Milnesium Doyère, 1840 (Tardigrada: Eutardigrada: Apochela). Contributions to Zoology 85, 173-200.

Morek W., Stec D., Gąsiorek P., Schill R.O., Kaczmarek . \& Michalczyk Ł. 2016. An experimental test of tardigrade preparation methods for light microscopy. Zoological Journal of the Linnean Society 178, 785-793.

Nelson D.R., Guidetti R. \& Rebecchi L. 2015. Phylum Tardigrada. In J. Thorp \& D.C. Rogers (eds.): Ecology and general biology: Thorp and Covich's freshwater invertebrates. Pp. 347-380. London: Academic Press.

Nielsen C. 2001. Animal evolution. Interrelationships of the living phyla. Oxford: Oxford University Press.

O'Gorman E.J., Pichler D.E., Adams G., Benstead J.P., Cohen H., Craig N., Cross W.F., Demars B.O.L., Friberg N., Gíslason G.M., Gudmundsdóttir R., Hawczak A., Hood J. M., Hudson L.N., Johansson L., Johansson M.P., Junker J.R., Laurila A., Manson J.R., Mavromati E., NelsoN D., Ólafsson J.S., Perkins D.M., Petchey O.L., Plebani M., Reuman D.C., Rall B.C., Stewart R., Thompson M.S. \& Woodward G. 2012. Impacts of warming on the structure and functioning of aquatic communities: individual to ecosystem-level responses. Advances in Ecological Research 47, 81-176.

Pilato G. 1981. Analisi di nuovi caratteri nello studio degli eutardigradi. (Analysis of new characters in the study of eutardigrades.) Animalia 8, 51-57.

Ramazzotti G. \& Maucci W. 1983. II Phylum Tardigrada. $3 r d$ edited and updated edn. Memorie dell'Istituto Italiano di Idrobiologia 41. Verbania Pallanza: Italian Institute of Hydrobiology.

Schill R.O., Jönsson K.I., Pfannkuchen M. \& Brümmer F. 2011. Food of tardigrades: a case study to understand food choice, intake and digestion. Journal of Zoological Systematics and Evolutionary Research 49, 66-70.

Schuster R. \& Greven H. 2013. Reproductive traits of Macrobiotus hufelandi during a long-term field study with notes on Paramacrobiotus richtersi and Diphascon pingue (Eutardigrada). Journal of Limnology 72, 166-174.

Seniczak S., Seniczak A., Graczyk R., Tømmervik H. \& Coulson S.J. 2017. Distribution and population characteristics of the soil mites Diapterobates notatus and Svalbardia paludicola (Acari: Oribatida: Ceratozetidae) in High Arctic Svalbard (Norway). Polar Biology 40, 1545-1555.

Stec D., Gąsiorek P., Morek W., Kosztyła P., Zawierucha K., Michno K., Kaczmarek Ł., Prokop Z.M. \& Michalczyk Ł. 2016. Estimating optimal sample size for tardigrade morphometry. Zoological Journal of the Linnean Society 178, 776-784.

Stempniewicz L., Błachowiak-Samołyk K. \& Węsławski J. M. 2007. Impact of climate change on zooplankton communities seabird populations and Arctic terrestrial ecosystem-a scenario. Deep Sea Research Part II: Topical Studies in Oceanography 54, 2934-2945.
Thackeray S.J., Sparks T.H., Frederiksen M., Burthe S., Bacon P.J., Bell J.R., Botham M.S., Brereton T.M., Bright P.W., Carvalho L., Clutton-Brock T., Dawson A., Edwards M., Elliott J.M., Harrington R., Johns D., Jones I.D., Jones J.T., Leech D.I., Roy D.B., Scott W.A., Smith M., Smithers R.J., Winfield I.J. \& Wanless S. 2010. Trophic level asynchrony in rates of phenological change for marine, freshwater and terrestrial environments. Global Change Boilogy 12, 3304-3313.

Trudnowska E., Basedow S.L. \& Blachowiak-Samolyk K. 2014. Mid-summer mesozooplankton biomass, its size distribution, and estimated production within a glacial Arctic fjord (Hornsund, Svalbard). The Journal of Marine Systems 137, 55-66.

Węsławski J.M., Kwaśniewski S., Stempniewicz L. \& Błachowiak-Samołyk K. 2006. Biodiversity and energy transfer to top trophic levels in two contrasting Arctic fjords. Polish Polar Research 27, 259-278.

Wojciechowska A., Zwolicki A., Barcikowski A. \& Stempniewicz L. 2015. The structure of Cochlearia groenlandica population along the bird colony influence gradient (Hornsund, Spitsbergen). Polar Biology 38, 1919-1930.

Wright J.C., Westh P. \& Ramløv H. 1992. Cryptobiosis in Tardigrada. Biological Reviews 67, 1-29.

Yvon-Durocher G., Maria Montoya J., Trimmer M. \& Woodward G. 2010. Warming alters the size spectrum and shifts the distribution of biomass in aquatic ecosystems. Global Change Biology 17, 1681-1694.

Zawierucha K., Cytan J., Smykla J., Wojczulanis-Jakubas K., Kaczmarek Ł., Kosicki J.Z. \& Michalczyk Ł. 2015. Seabird guano boosts body size of water bears (Tardigrada) inhabiting the Arctic tundra. Polar Biology 38, 579-582.

Zawierucha K., Ostrowska M., Vonnahme T.R., Devetter M., Nawrot A.P., Lehmann S. \& Kolicka M. 2016. Diversity and distribution of Tardigrada in Arctic cryoconite holes. Journal of Limnology 75, 545-559.

Zawierucha K., Zmudczyńska-Skarbek K., Kaczmarek Ł. \& Wojczulanis-Jakubas K. 2016. The influence of a seabird colony on abundance and species composition of water bears (Tardigrada) in Hornsund (Spitsbergen, Arctic). Polar Biology 39, 713-723.

Zmudczyńska K., Olejniczak I., Zwolicki A., Iliszko L., Convey P. \& Stempniewicz L. 2012. Influence of allochtonous nutrients delivered by colonial seabirds on soil collembolan communities on Spitsbergen. Polar Biology 35, 1233-1245.

Zmudczyńska K., Zwolicki A., Barcikowski M., Iliszko L. \& Stempniewicz L. 2008. Variability of individual biomass and leaf size of Saxifraga nivalis L. along a transect between seabirds colony and seashore in Hornsund, Spitsbergen. Ecology Quest 9, 37-44.

Zmudczyńska-Skarbek K., Barcikowski M., Zwolicki A., Iliszko L. \& Stempniewicz L. 2013. Variability of polar scurvygrass Cochlearia groenlandica individual traits along a seabird influenced gradient across Spitsbergen tundra. Polar Biology 36, 1659-1669.

Zwolicki A., Zmudczyńska-Skarbek K., Iliszko L. \& Stempniewicz L. 2013. Guano deposition and nutrient enrichment in the vicinity of planktivorous and piscivorous seabird colonies in Spitsbergen. Polar Biology 36, 363-372.

Zwolicki A., Zmudczyńska-Skarbek K., Richard P. \& Stempniewicz L. 2016. Importance of marine-derived nutrients supplied by planktivorous seabirds to High Arctic tundra plant communities. PLoS One 11, e0154950, doi: 10.1371/journal.pone.0154950. 